Care: Jurnal Ilmiah Ilmu Kesehatan Vol .7, No.1,2019,hal 53-63

Tersedia online di https://jurnal.unitri.ac.id/index.php/care

ISSN 2527-8487 (online)

ISSN 2089-4503 (cetak)

\title{
Faktor Predisposisi Pengetahuan, Sikap, Nilai dan Budaya Eks Wanita Pekerja Seksual dengan Kejadian HIV/AIDS di Wilayah Kediri
}

\author{
Indah Jayani ${ }^{1,}$ Fatma Sayekti Ruffaida ${ }^{2}$ \\ ${ }^{1,2}$ Health Sciences Faculty, Universitas Kadiri \\ e-mail: indah.jayani@unik-kediri.ac.id
}

\begin{abstract}
Human Immunodeficiency V irus (HIV)/ Immuno Deficiency Syndrome (AIDS) is a global health problem as a cause of a high mortality rate. The phenomenon of an increase in HIV/AIDS infection in the Kediri region was mostly obtained from the former Sexual Workers Woman (WPS). The purpose of the study was to determine the correlation between knowledge, attitudes, values and culture with the prevalence of HIV/AIDS among former sexual worker women in Kediri, East Java Province. This study was a correlation analytic study with a cross sectional. The population in this study was 448 with a proportional stratifed sampling technique which obtained a sample of 58 people. The instrument used in data collection is questionnaire. The results of the analysis with the Spearman rank correlation test showed there was a strong negative correlation between knowledge with HIV/AIDS events ( $\varrho=0,00 ; r=-0,571)$, a strong negative correlation between attitudes and HIV/AIDS events $(\varrho=0,00 ; r=-0,538)$, a strong negative correlation between value and HIV/AIDS events $(\varrho=0,00 ; r=-0,784)$ and a strong negative correlation between cultures and HIV/AIDS events was indicated by $(\varrho=0,00 ; r=-0,456)$ among former WPS in Kediri, East Java Province 2017. Based on the results, the suggestions for health workers and related social services should continue to improve services by providing continuous education to former WPS related to how HIV / AIDS prevention and transmission are carried out, providing assistance, monitoring bio, psycho, sociospiritual to change attitudes maladaptive becomes adaptive, and to disseminate culture to reduce the risk of HIV / AIDS.
\end{abstract}

Keywords: attitudes; culture; HIV / AIDS; knowledge; values

\begin{abstract}
ABSTRAK
Penyakit infeksi Human Immunodeficiency Virus (HIV)/ Immuno Deficiency Syndrome (AIDS) merupakan masalah kesehatan global sebagai penyebab angka kematian yang cukup tinggi. Fenomena peningkatan prevalensi infeksi HIV/AIDS di wilayah Kediri terbanyak didapatkan dari eks Wanita Pekerja Seksual (WPS). Tujuan penelitian ini adalah untuk mengetahui hubungan antara pengetahuan, sikap, nilai dan budaya dengan kejadian HIV/AIDS di wilayah Kediri. Desain penelitian ini menggunakan analitik korelasi dengan pendekatan cross sectional. Dari populasi 448 dengan teknik proportional stratifed sampling didapatkan sampel sejumlah 58 orang. Instrumen yang digunakan dalam pengambilan data menggunakan kuisioner. Hasil di analisis menggunaka uji korelasi spearman rank, didapatkan hubungan negatif cukup kuat antara pengetahuan dengan kejadian HIV/AIDS $(\varrho=0,00 ; r=-0,571)$, hubungan negatif cukup kuat antara sikap dengan kejadian HIV/AIDS
\end{abstract}


$(\varrho=0,00 ; \mathrm{r}=-0,538)$, hubungan negatif kuat antara nilai dengan kejadian HIV/AIDS $(\varrho=0,00 ; \mathrm{r}=-0,784)$, dan hubungan negatif cukup kuat antara budaya dan kejadian HIV/AIDS ditunjukkan dengan $(\varrho=0,456 ; r=-0,456)$ pada eks WPS di wilayah Kediri tahun 2017. Saran untuk petugas kesehatan dan pelayanan sosial yang terkait terus meningkatkan pelayanan dengan memberikan edukasi yang kontinyu pada eks WPS terkait dengan bagaimana upaya pencegahan dan penularan HIV/AIDS, melakukan pendampingan, memantau bio, psiko, sosio spiritual untuk merubah sikap maladaptif menjadi adaptif, dan menanamkan nilai dan budaya untuk menurunkan resiko HIV/AIDS.

Kata Kunci : budaya; HIV/ AIDS; nilai; pengetabuan; sikap

\section{PENDAHULUAN}

Permasalahan penyakit infeksi Human Immunodeficiency Virus (HIV) dan Acquired Immuno Deficiency Syndrome (AIDS) merupakan sebuah fenomena gunung es karena jumlah kasus pasti tidak mencerminkan masalah yang sebenarnya. Dampak kebijakan pemerintah menutup sejumlah lokalisasi menuai pandangan positif dan negatif dari berbagai aspek. Di wilayah Kediri, hampir sebagian besar area lokalisasi yang tersebar di beberapa wilayah kota dan kabupaten Kediri secara legal telah ditutup tetapi aktivitas seksual tidak berhenti begitu saja. Hal ini ditunjukkan dengan banyak ditemukan kasus baru HIV/ AIDS dari eks PSK. Secara global peningkatan jumlah penderita HIV/AIDS banyak dijumpai pada usia dewasa, pemakai NAPZA, pekerja seks dan pelanggan (Kemenkes, 2017).

Laporan Ditjen P2P, Kemenkes RI, tahun 2017 didapatkan kasus kumulatif
HIV/AIDS di Indonesia priode tahun 1987 sampai dengan 30 Juni 2015 sebanyak 291.465 kasus yang terdiri atas 208.909 kasus HIV dan 82.556 kasus AIDS dengan 14.234 kematian. Jawa Timur menempati rangking kedua dengan angka kejadian HIV 27.575 kasus dan AIDS 16.431 kasus sehingga total penderita HIV/AIDS sebesar 44.006 orang. Di wilayah Kediri, jumlah kasus HIV/AIDS cenderung meningkat beberapa tahun terakhir, terhitung dari tahun 2012 hingga September 2016 tercatat 811 penderita HIV-AIDS (Dinas Kesehatan Kabupaten Kediri, 2016).

Menurut survei yang dilakukan peneliti, angka kesakitan HIV/AIDS dari eks pekerja seksual cukup tinggi. Dari 69 ODHA baru, didapatkan 48\% mempunyai riwayat bekerja sebagai PSK. Penyebab peningkatan infeksi HIV pada PSK disebabkan rendahnya pengetahuan dan sikap PSK mengenai penyakit HIV/AIDS. Dari 10 eks PSK, sebanyak $80 \%$ menyebutkan tidak tahu bagaimana 
perjalanan penyakit HIV/AIDS dan enggan melakukan pemeriksaan kesehatan karena merasa tidak ada keluhan, diantaranya 60\% menyebutkan bahwa di lingkungan tempat tinggal tidak merasa dikucilkan karena sudah merupakan hal biasa. Hal tersebut menunjukkan bahwa pengetahuan, sikap nilai dan budaya dari eks PSK masih rendah.

Penderita HIV terjadi kehilangan CD4 yang masif baik oleh akibat virus sendiri maupun aktivasinya pada sistem imun yang dapat menyebabkan apoptosis CD4. Kehilangan CD4 dikarenakan produksi pada sumsum tulang yang menurun, peningkatan degradasi pada organ limfoid dan penggunaannya yang meningkat. Ketidakseimbangan proses tersebut mempengaruhi progresivitas infeksi HIV (Maya Savira, 2014). Perjalanan penyakit sejak seseorang terkena infeksi HIV hingga menjadi AIDS umumnya berlangsung dalam jangka waktu delapan sampai sepuluh tahun jika tidak disertai terapi Anterotroviral (ARV) (Detels R, Munoz a, McFarlane G, Kingsley LA, Margolick JB, Giorgi J, Schrager LK, 1998)

Virus HIV masuk dalam tubuh manusia dan mempengaruhi mekanisme respon imun. Respon yang terjadi diawali dengan mekanisme up regulation, kemudian diikuti down regulation karena kegagalan dalam mekanisme adaptasi sistem imun. Dampak dari mekanisme imunitas tersebut menyebabkan tubuh menjadi rentan terhadap infeksi oportunistik. Infeksi oportunistik pada pengidap HIV di Indonesia, potensial lebih awal munculnya karena bukan saja akibat semakin melemahnya sistem imun yang terserang HIV tetapi juga pengaruh lingkungan (Nasronudin, Barakbah J, Soewandojo E, Suharto, Hardi U, 2007)

Di Indonesia, terdapat populasi tertentu yang merupakan fokus perhatian dalam upaya peningkatan pelayanan kesehatan. Komisi Penanggulangan AIDS Kota Kediri mengarahkan pada populasi beresiko tinggi. Menurut data (Dinas Kesehatan Kabupaten Kediri, 2017) kelompok rentan, kelompok berisiko tertular dan kelompok tertular yang paling beresiko diantaranya adalah WPS. Termasuk kelompok rentan adalah orang yang mempunyai lingkup pekerjaan, lingkungan, rendahnya ketahanan dan kesejahteraan keluarga, status kesehatan, sehingga menyebabkan terhadap penularan infeksi HIV.

Kelompok rentan meliputi kelompok pertama yaitu kelompok orang dengan 
mobilitas tinggi (khususnya laki-laki), perempuan, remaja, anak jalanan, keluarga miskin, ibu hamil, dan orang yang menjalani transfusi darah. Kelompok kedua adalah kelompok orang yang beresiko tertular yaitu orang yang berperilaku resiko tinggi seperti; berganti pasangan seks tanpa menggunakan kondom, penjaja seks bebas, penggunaan alat suntik secara bergantian dan napza suntik serta kelompok yang ketiga adalah kelompok tertular yaitu orang yang sudah terinfeksi HIV. Populasi dari tiga kelompok tersebut merupakan kunci populasi yang menentukan keberhasilan program pemerintah dalam pencegahan dan dan penanggulangan HIV/AIDS, sehingga besar kontribusi mereka untuk aktif berperan dalam program pencegahan dan penanggulangan HIV/AIDS (Dinas Kesehatan Kabupaten Kediri, 2016).

Berdasarkan fenomena diatas peneliti ingin mengetahui hubungan faktor pengetahuan, sikap, nilai dan budaya dengan kejadian HIV/AIDS di wilayah Kediri.

\section{METODE PENELITIAN}

Rancangan penelitian ini menggunakan desain analitik korelasional dengan pendekatan cross sectional untuk mengidentifikasi faktor predisposisi pengetahuan, sikap, nilai dan budaya dengan kejadian HIV/AIDS pada eks WPS di wilayah Kediri. Penelitian ini mengambil sejumlah populasi dari $448 \mathrm{eks}$ WPS di wilayah Kediri dan dengan menggunakan teknik proportional stratifed sampling, didapatkan sampel sejumlah 58 orang (Daniel, 1999). Variabel independen dalam penelitian ini adalah pengetahuan sikap, nilai dan budaya sedangkan variabel dependen adalah kejadian HIV/AIDS. Instrumen yang digunakan adalah kuisioner, sedangkan untuk analisis data untuk mengetahui hubungan antara faktor pengetahuan, sikap, nilai dan budaya dengan kejadian HIV/AIDS digunakan uji korelasi menggunakan spearman rank. Penelitian ini telah melalui uji etik di Komite Etik Fakultas Ilmu Kesehatan Masyarakat (FKM) Universitas Airlangga Surabaya dengan no sertifikat No. 429-KEPK.

\section{HASIL}

Tabel 1 menunjukkan kelompok usia responden tertinggi 21-35 tahun berjumlah 39 orang (65,5\%); riwayat pendidikan responden yang paling banyak adalah menengah yaitu sebanyak 44 orang $(75,9 \%)$; pekerjaan responden saat ini terbanyak adalah ibu rumah tangga yaitu sebanyak 27 orang $(46,6 \%)$. 
Tabel 2 menunjukkan sebagian besar responden 58,7\% eks WPS memiliki pengetahuan kurang. Hasil analisa data yang menggunakan uji Spearman rank didapatkan hasil nilai $\varrho$ value $=0,000<\alpha$ $=0,00$, maka $\mathrm{H}_{0}$ ditolak dan $\mathrm{H}_{1}$ diterima. Berarti ada hubungan antara pengetahuan dengan kejadian HIV/AIDS pada eks WPS di wilayah Kediri tahun 2017 dengan nilai coefficient correlation cukup kuat, yaitu sebesar $\mathrm{r}=-0,571$ dengan makna arah korelasi negatif, semakin rendah pengetahuan semakin tinggi kejadian HIV / AIDS.

Tabel 1. Karakteristik responden berdasarkan usia, pendidikan dan pekerjaan ( $\mathrm{n}=58)$

\begin{tabular}{llcc}
\hline Variabel & & Jumlah & $\%$ \\
\hline Usia & $<20$ & 2 & 3,4 \\
& $21-35$ & 39 & 65,5 \\
\multirow{5}{*}{ Pendidikan } & $>35$ & 18 & 31,0 \\
& Dasar & 11 & 19,0 \\
& Menengah & 44 & 75,9 \\
& Tinggi & 3 & 5,2 \\
& IRT & 27 & 46,6 \\
& Swasta & 16 & 27,6 \\
& Wiraswasta & 6 & 10,3 \\
& Lainnya & 9 & 15,5 \\
\hline
\end{tabular}

Tabel 2. Hubungan antara pengetahuan dengan kejadian HIV/AIDS

\begin{tabular}{lccc}
\hline $\begin{array}{l}\text { Faktor } \\
\text { Pengetahuan }\end{array}$ & \multicolumn{3}{c}{ Kejadian HIV/AIDS } \\
\hline & $\begin{array}{c}\text { Tidak HIV /AIDS } \\
\text { Jumlah(\%) }\end{array}$ & $\begin{array}{c}\text { HIV /AIDS } \\
\text { Jumlah }(\%)\end{array}$ & $\begin{array}{c}\text { Total } \\
\text { Jumlah }(\%)\end{array}$ \\
\hline Baik & $8(13,8)$ & $2(6,9)$ & $10(17,2)$ \\
Cukup & $10(17,2)$ & $4(10,3)$ & $14(24,1)$ \\
Kurang & $18(31)$ & $16(20,7)$ & $34(58,7)$ \\
Total & $36(62,1)$ & $22(37,9)$ & $58(100)$ \\
Sig.(2-tailed) $=0,00$ & & Coefisien correlation $=-0,571$ \\
\hline
\end{tabular}

Berdasarkan Tabel 3 dapat kejadian HIV/AIDS pada eks WPS di diinterpretasikan bahwa sebagian besar wilayah Kediri tahun 2017, dengan nilai responden 60,4\% eks WPS memiliki sikap coefficient correlation cukup kuat, yaitu kurang. Hasil analisa data yang sebesar $\mathrm{r}=-0,578$ dengan makna arah menggunakan uji Spearman rank korelasi negatif, semakin rendah sikap didapatkan hasil nilai $\varrho$ value $=0,000<\alpha$ semakin tinggi kejadian HIV/AIDS.

$=0,05$, maka $\mathrm{H}_{0}$ ditolak dan $\mathrm{H}_{1}$ diterima.

Berarti ada hubungan antara sikap dengan 
Tabel 3. Hubungan antara sikap dengan kejadian HIV/AIDS

\begin{tabular}{lccc}
\hline Faktor Sikap & \multicolumn{3}{c}{ Kejadian HIV/AIDS } \\
\hline & $\begin{array}{c}\text { Tidak HIV/AIDS } \\
\text { Jumlah }(\%)\end{array}$ & $\begin{array}{c}\text { HIV/AIDS } \\
\text { Jumlah }(\%)\end{array}$ & $\begin{array}{c}\text { Total } \\
\text { Jumlah }(\%)\end{array}$ \\
\hline Baik & $7(12,1)$ & $2(6,9)$ & $9(15,5)$ \\
Cukup & $10(17,2)$ & $4(13,8)$ & $14(24,1)$ \\
Kurang & $19(32,8)$ & $16(17,2)$ & $35(60,4)$ \\
Total & $36(62,1)$ & $22(37,9)$ & $58(100)$ \\
Sig. (2-tailed) $=0,00$ & & Coefisien correlation=-=-0,578 \\
\hline
\end{tabular}

Tabel 4. Hubungan antara nilai dan kepercayaan dengan kejadian HIV/AIDS

\begin{tabular}{|c|c|c|c|}
\hline $\begin{array}{l}\text { Faktor } \\
\text { Nilai }\end{array}$ & \multicolumn{3}{|c|}{ Kejadian HIV/AIDS } \\
\hline & $\begin{array}{l}\text { Tidak HIV/AIDS } \\
\text { Jumlah }(\%)\end{array}$ & $\begin{array}{l}\text { HIV/AIDS } \\
\text { Jumlah (\%) }\end{array}$ & $\begin{array}{c}\text { Total } \\
\text { Jumlah }(\%)\end{array}$ \\
\hline Baik & $9(15,5)$ & $2(3,4)$ & $11(19)$ \\
\hline Cukup & $11(19)$ & $9(15,5)$ & $20(34,5)$ \\
\hline Kurang & $16(27,6)$ & $11(19)$ & $27(46,5)$ \\
\hline Total & $36(62,1)$ & $22(37,9)$ & $58(100)$ \\
\hline \multicolumn{2}{|c|}{ Sig. $(2$-tailed $)=0,00$} & \multicolumn{2}{|c|}{ Coefisien correlation $=-0,784$} \\
\hline
\end{tabular}

Tabel 5. Hubungan antara budaya dengan kejadian HIV/AIDS

\begin{tabular}{lccc}
\hline $\begin{array}{l}\text { Faktor } \\
\text { Budaya }\end{array}$ & \multicolumn{3}{c}{ Kejadian HIV/AIDS } \\
\hline & $\begin{array}{c}\text { Tidak HIV/AIDS } \\
\text { Jumlah }(\%)\end{array}$ & $\begin{array}{c}\text { HIV/AIDS } \\
\text { Jumlah }(\%)\end{array}$ & $\begin{array}{c}\text { Total } \\
\text { Jumlah }(\%)\end{array}$ \\
\hline Baik & $18(31)$ & $2(3,4)$ & $20(34,5)$ \\
Cukup & $11(19)$ & $4(6,9)$ & $15(25,9)$ \\
Kurang & $7(12,1)$ & $16(27,6)$ & $23(39,6)$ \\
Total & $36(62,1)$ & $22(37,9)$ & $58(100)$ \\
Sig.(2-tailed $)=0,00$ & Coefisien correlation $=-0,456$ \\
\hline
\end{tabular}

Berdasarkan Tabel 4 diinterpretasikan bahwa hampir sebagian (46,5\%) eks WPS mempunyai nilai yang kurang. Hasil analisa data yang menggunakan uji Spearman rank didapatkan hasil nilai $\varrho$ value $=0,00>\alpha=0,05$, maka $\mathrm{H}_{0}$ ditolak dan $\mathrm{H}_{1}$ diterima berarti ada hubungan antara nilai dengan kejadian HIV/AIDS pada eks WPS di wilayah Kediri tahun
2017 dengan nilai coefficient correlation kuat, yaitu sebesar $\mathrm{r}=-0,784$ dengan makna arah korelasi negatif, semakin rendah nilai semakin tinggi kejadian HIV/AIDS.

Berdasarkan Tabel 5 diinterpretasikan bahwa hampir sebagian responden 39,6\% eks WPS memiliki budaya kurang. Hasil analisa data yang menggunakan uji 
Spearman rank didapatkan hasil nilai $\varrho$ value $=0,35>\alpha=0,05$, maka $\mathrm{H}_{1}$ ditolak dan $\mathrm{H}_{0}$ diterima yang berarti ada hubungan antara budaya dengan kejadian HIV/AIDS pada eks WPS di wilayah Kediri tahun 2017, dengan nilai coefficient correlation cukup kuat, yaitu sebesar $r=-0,456$ dengan makna arah korelasi negatif, semakin rendah budaya semakin tinggi kejadian HIV/AIDS.

\section{PEMBAHASAN}

Hasil penelitian menunjukkan sebagian besar berusia 21-35 tahun. Responden yang merupakan eks WPS paling banyak berusia produktif. Dimana usia produktif merupakan usia yang rentan terhadap penularan HIV/AIDS. Penelitian lain menunjukkan bahwa usia muda lebih beresiko terhadap perilaku seksual tidak aman sehingga kurang dalam melakukan tindakan pencegahan penularan HIV dibandingkan dengan umur tua, meskipun pada beberapa kasus umur tua dapat juga berperilaku seks beresiko (Yowel Kambu, Agung Waluyo, 2016).

Riwayat pendidikan responden yang sebagian besar adalah menengah. Eks WPS tidak melanjutkan ke jenjang pendidikan tinggi dan lebih memilih sebagai WPS setelah lulus SMA. Penelitian yang serupa didapatkan ada pengaruh pendidikan terhadap perilaku pencegahan HIV/AIDS pada Pekerja Seks Komersial dimana wanita berpendidikan $\geq$ SMA mempunyai kemungkinan 1,54 kali lebih besar untuk melakukan pencegahan HIV/AIDS dibandingkan wanita pekerja seks dengan wanita pekerja seksual yang berlatar pendidikan < SMA (Ratnaningsih, 2016). Seseorang yang berpendidikan tinggi memiliki penyerapan dan pemahaman terhadap informasi kesehatan lebih baik, khususnya informasi kesehatan upaya pencegahan penularan HIV/AIDS (Yowel Kambu, Agung Waluyo, 2016).

HIV merupakan virus yang menyerang sistem kekebalan tubuh. Perjalanan infeksi HIV didalam tubuh menyerang sel Cluster of Differentiation 4 (CD4) sehingga terjadi penurunan sistem pertahanan tubuh. Tahapan akhir infeksi HIV sampai muncul tanda dan gejala AIDS memerlukan waktu yang cukup lama yaitu 10 sampai 13 tahun (Brunner dan Suddarth, 2002).

Kebiasaan perilaku seks bebas, menurunnya nilai agama dan kebiasaan budaya, mempunyai risiko terhadap terjangkitnya penyakit HIV/AIDS. Faktor lain yang mendukung ekonomi/pekerjaan, gaya hidup, dan rumah tangga yang retak, pengaruh lingkungan sosial mempunyai 
pengaruh besar terhadap risiko terjangkitnya penyakit HIV/AIDS.

Pengetahuan eks WPS di wilayah Kediri sebagian besar kurang. Hal ini sesuai dengan latar pendidikan dimana 75,9\% adalah pendidikan menengah. Menurut peneliti eks WPS di wilayah Kediri tahun 2017 cenderung memiliki pendidikan yang kurang sehingga penyerapan informasi tidak dapat maksimal dipahami sehingga pengetahuannya juga kurang. Dampak dari pengetahuan yang kurang maka sikap eks WPS juga kurang. Hasil penelitian lain yang terkait pengetahuan yang rendah berpotensi perilaku beresiko HIV/AIDS (Meizhen Liao, Mei Wang, Xingjie Shen, Pengxiang Huang, Xingguang Yang, Lianzheng Hao, Catherine Cox, Pingsheng Wu, Xiaorun Tao, Dianmin Kang, 2015)

Pengetahuan merupakan dasar untuk menghadapi permasalahan yang dihadapi sehari-hari sehingga pengetahuan akan berguna untuk manusia dalam bertingkah laku. Hasil penelitian yang mendukung adalah ada pengaruh pengetahuan terhadap status HIV/AIDS pada IRT melalui sikap dan pola seksual (Budi Laksana, Argyo Demartoto, 2017)
Hasil penelitian lain menunjukkan hasil yang sama yaitu pengetahuan tinggi pada pekerja seksual komersial mempunyai kemungkinan 2,31 kali lebih besar untuk melakukan pencegahan HIV/AIDS dibandingkan dengan pekerja seks komersial dengan pengetahuan rendah (Dwi Ratnaningsih, 2016). Penerimaan perilaku baru atau adopsi perilaku melalui proses yang didasari oleh pengetahuan, kesadaran dan sikap yang positif, maka perilaku tersebut akan bersifat langgeng (long lasting) daripada perilaku yang tidak didasari oleh pengetahuan. Pengetahuan atau kognitif merupakan domain yang sangat penting dalam membentuk tindakan seseorang dalam hal ini pengetahuan yang tercakup dalam domain kognitif (Notoadmodjo, 2003).

Nilai dan kepercayaan eks WPS di wilayah Kediri sebagian besar kurang. Menurut peneliti nilai merupakan dasar yang haqiqi manusia sebagai bentuk pengharapan yang baik atas dirinya yang dipengaruhi oleh kelompoknya. Eks WPS mempunyai nilai dan kepercayaan yang kurang dapat disebabkan oleh pengaruh sosial dimana mereka tinggal dalam masyarakat yang sebagian besar mempunyai kebiasaan yang sama. 
Menurut (Asrori, 2010) nilai panduan dalam mempertimbangkan keputusan membuat keputusan mengenai apa yang ingin dicapai atau sebagai sesuatu yang dibutuhkan. Secara dinamis, nilai dipelajari dari produk sosial dan secara perlahan diinternalisasikan oleh individu serta diterima sebagai milik bersama dengan kelompoknya.

Budaya eks WPS di wilayah Kediri hampir sebagian kurang (39,6\%). Tinggal di lokalisasi menanamkan budaya masyarakat cenderung bebas. Melakukan seks bebas adalah sesuatu hal yang biasa. Budaya eks WPS melekat hingga saat ini meskipun sudah tidak menjadi lokalisasi. Budaya merupakan kebiasaan yang dimiliki bersama oleh sebuah kelompok orang dan diwariskan dari generasi ke generasi. Unsur dari budaya dibentuk dari berbagai unsur, antara lain sistem politik, agama, adat istiadat, bangunan, karya seni, bahasa. Budaya merupakan bagian yang tak terpisahkan dari diri manusia sehingga dapat dianggap sebagai pewarisan genetik. Menurut penelitian yang dilakukan oleh (Susilowati, 2011) salah satu faktor yang berpengaruh terhadap kejadian HIV/AIDS adalah budaya/etnik. Penelitian lain yang mendukung adalah etnis laki-laki dengan ras kulit hitam beresiko terhadap perilaku beresiko HIV
AIDS (Jeffrey A, Kelly, Janet S. St. lawrence, Yuri A., amirkhanian, Wayne J. Difransisco, Michelle Anderson-Lam, Luis I. Gracia, 2013).

\section{KESIMPULAN}

1. Ada hubungan antara faktor pengetahuan dengan kejadian HIV/AIDS di wilayah Kediri tahun 2017.

2. Ada hubungan antara faktor sikap kejadian HIV/AIDS di wilayah Kediri tahun 2017.

3. Ada hubungan antara faktor nilai kejadian HIV/AIDS di wilayah Kediri tahun 2017.

4. Ada hubungan antara faktor budaya kejadian HIV/AIDS di wilayah Kediri tahun 2017.

Saran untuk petugas kesehatan dan pelayanan sosial yang terkait agar terus meningkatkan pelayanan dengan memberikan edukasi yang kontinyu pada eks WPS terkait dengan bagaimana upaya pencegahan dan penularan HIV/AIDS, melakukan pendampingan, memantau bio, psiko, sosio spiritual untuk merubah sikap maladaptif menjadi positif, dan meningkatkan nilai dan budaya yang dapat meningkatkan resiko HIV/AIDS. 


\section{UCAPAN TERIMAKASIH}

Terimakasih disampaikan pada Kementerian Riset, Teknologi dan Pendidikan Tinggi Republik Indonesia penelitian yang telah memberikan dana penelitian. Terimakasih pada LP3M Universitas Kadiri yang telah memberikan dukungan penuh untuk menyelesaikan penelitian.

\section{REFERENSI}

Asrori, M. A. dan M. (2010). Psikologi Remaja (Perkembangan Peserta Didik). PT Bumi Aksara: Jakarta.

Brunner dan Suddarth. (2002). Buku Ajar Keperawatan Medikal Bedah. EGC: Jakarta.

Budi Laksana, Argyo Demartoto, D. I. (2017). Knowledge, Attitude, Sexual Behavior, Family Support, and Associations with HIV/AIDS Status in Housewives. Journal of Epidemiology and Public Health, 2(2), 154-163.

Daniel, W. (1999). Biostatistics: A Fondation for Analysis in the Health Sciences. 7th edition. New York: John Wiley \& Sons.

Depkes, 2018. (2018). Situasi HIV/AIDS di Indonesia. Retrieved from www.depkes.go.id

Detels R, Munoz a, McFarlane G, Kingsley LA, Margolick JB, Giorgi J, Schrager LK, P. J. (1998). Effectiveness of potent Antiretroviral Theraphy On Time To AIDS and Death in Men with Known HIV Infection Duration. Multicenter AIDS Cohort Study Investigators. Pub Med, 280(17), 1497-1503.

Dinas Kesehatan Kabupaten Kediri. (2016). Profil Kesehatan Kabupaten Kediri Tabun 2016. Retrieved from www.dinkes.kedirikab.go.id

Dinas Kesehatan Kabupaten Kediri.
(2017). Profil Kesehatan Kabupaten Kediri Tabun 2016. Retrieved from www.dinkes.kedirikab.go.id

Dwi Ratnaningsih. (2016). Perilaku Pencegahan HIV/AIDS pada Wanita Pekerja Seks Komersial. Universitas Sebelas Maret. Retrieved from http:uns.ac.id

Jeffrey A, Kelly, Janet S. St. lawrence, Yuri A., amirkhanian, Wayne J. Difransisco, Michelle AndersonLam, Luis I. Gracia, and M. T. N. (2013). Levels and Predictors of HIV Risk Behavior Among Black Men Who Have Sex with Men. Aids Education and Prevention, 25(1), 49-61.

Kemenkes, R. (2017). Laporan Perkembngan HIV-AIDS \& Penyakit Infeksi Menular Seksual (PIMS) Triwulan I Tabun 2017.

Maya Savira. (2014). Imunologi Human Immunodeficiency Virus (HIV) dalam Kehamilan. JIK, 1-7. https://doi.org/10.26891

Meizhen Liao, Mei Wang, Xingjie Shen, Pengxiang Huang, Xingguang Yang, Lianzheng Hao, Catherine Cox, Pingsheng Wu, Xiaorun Tao, Dianmin Kang, Y. J. (2015). Bisexual Behaviors, HIV Knoeledge, and Stigmatizing/ Discriminatory Attitudes Among Men Who Have Sex With Men. Plos One. https://doi.org/10.1371

Nasronudin, Barakbah J, Soewandojo E, Suharto, Hardi U, A. W. (2007). Penatalaksanaan Klinis Infeksi HIV \& AIDS. Dalam: HIV AIDS, Pendekatan Biologi Molekuler, Klinis dan Sosial. Universitas Airlangga Surabaya, 31-43.

Notoadmodjo, S. (2003). Pendidikan dan Perilaku Kesehatan. Rineka Cipta: Jakarta.

Ratnaningsih, D. (2016). Faktor-Faktor Yang Mempengaruhi Perilaku Pencegahan HIV/AIDS pada Wanita Pekerja Seks Komersial. Universitas Sebelas Maret. 
Care: Jurnal Ilmiah Ilmu Kesehatan Vol .7, No.1,2019, hal 53-63

Susilowati, T. (2011). Faktor-Faktor Risiko Yang Berpengaruh Terhadap Kejadian HIV dan AID di Semarang dan Sekitarnya, http://e-journalakbidpurworejo.ac.id/index.php/jk.

Yowel Kambu, Agung Waluyo, K. (2016). Umur Orang Dengan HIV AIDS (ODHA) Berhubungan Dengan
Tindakan Pencegahan Penularan HIV. Jurnal Keperawatan Indonesia, 19(3), 200-207. https://doi.org/10.7454/jki.v19i3.4 73 